\title{
PERLUNYA EVALUASI KINERJA PARASITOID PADA HAMA DAUN KELAPA : BRONTISPA LONGISSIMA GESTRO (COLEOPTERA: CHRYSOMELIDAE) DI KABUPATEN ENDE-FLORES
}

\author{
Sri Wahyuni \\ Program Studi Agroekoteknologi Fakultas Pertanian Universitas Flores \\ sriwahyuni_uniflor@yahoo.co.id
}

\section{SUMMARY}

\section{Evaluation of Parasitoid Activity on Coconut Leaf Pest : Brontispa longissima Gestro (Coleoptera:ChrysomeIidae) in Ende - Flores}

Brontispa longissima Gestro (Coleoptera:Chrysomelidae) is ones of the most important pest who attack of many family palm in South East Asia. In Indonesia, Brontispa longissima has. becomes a primer pest on coconut. It was Decreasing yield result up to $30-40 \%$ returns and 5\% of the attacked crops will be die.

Ones of the failed reason of control action is low preventive system on every territory entrance, otherwise coconut was needful and fast moving commodity for people and industry. The second reason is secondary commodity assume and low cropping system caused pest and disease uncontrolized. Three bio-control usage on field need to monitored caused farmers uncapable.

The success indicator for parasitoid release was quick and easy to adapt for the parasitoid. It was related " three generation three years " teory by Ev Chausen , the expert of integrated pest and management control from California says : a) The perfectly of Effective parasitoid/predator always quick and easy to adapt, b) The failed parasitoid/predator to adapt easy and quickly was uneffective indicator for bio-control, c) Parasitoid release or excotic predator could be stopped for 3 years if no evidence adapt on fields. According to the experts, the key for success of system controlling above depend on cropping agroecosystem stability.

\section{Key Word : Brontispa longissima, Parasitoid, Predator}

\section{PENDAHULUAN}

\section{Brontispa longissima Gestro} (Coleoptera:Chrysomelidae) merupakan salah satu hama penting yang menyerang bangsa palm-palman di Asia Tenggara (Hosang, 2008), Dari 17 jenis palm termasuk didalamnya adalah kelapa, nipa, pinang dan beberapa tanaman hias menjadi inang dari $B$. longissima. Di beberapa provinsi di Indonesia hama tersebut telah menjadi hama utama pada kelapa. Dilaporkan penurunan hasil akibat serangan hama tersebut mencapai $30-40 \%$ dan 5\% dari tanaman yang terserang mengalami kematian (Nakamura, 2006). Penurunan hasil tersebut dianggap bernilai besar sebab penghasilan yang diperoleh dari kelapa tidak sebesar penghasilan dari komediti perkebunan yang lain dimana harga kelapa dipasaran re kit if rendah jika dibandingkan dengan komoditi perkebunan umumnya. Upaya pengendalian telah dilakukan sejak hama tersebut ditemukan di Indonesia pada tahun 1919 - 1934 (Nakamura, 2006) namun hama tersebut tetap eksis. Pelepasan parasitoid T. brontispe terakhir dilakukan pada bulan Desember 2007 dan Januari 2008 sejumlah 5.220 ekor. Tingkat populasi $B$. longissima di lapang pada saat setelah dilakukan pelepasan musuh alami mengalami penurunan tetapi belum dapat mengendalikan populasi hama pada musim selanjutnya hal tersebut diperlihatkan dengan kemunculan $B$. longissima setiap tahun dengan intensitas serangan berat terutama pada bulan bulan kering dan puncak penyerangannya terjadi pada bulan Januari - April.

Hama B. longissima dapat menyerang tanaman pada semua stadia umur, tetapi serangannya paling banyak ditemukan pada saat tanaman mulai berumur 4-5 tahun khusus di daerah beriklim kering tingkat serangan hama tersebut lebih tinggi (Hosang 2008). Larva dan serangga dewasa $B$. longissima menyerang jaringan daun muda (janur) kelapa, dengan gejala serangan daun berubah warna menjadi coklat sampai putih dan mengering. Gejala serangan tersebut mengakibatkan berkurangnya area fotosintesis yang tentunya secara tidak langsung dapat menurunkan produksi buah kelapa bahkan pada serangan berat akan mengakibatkan kematian pada tanaman (Gambar 1).

Upaya pengendalian telah dilakukan sejak hama tersebut ditemukan di Indonesia pada tahun 1919 - 1934 (Nakamura, 2006) namun hama tersebut tetap eksis. Dalam RENSTRA DISHUTBUN Kab. Ende untuk tahun 2006 - 
2010 tertuang program peningkatan produktivitas tanaman perkebunan dengan salah satu upayanya adalah melakukan pengendalian OPT pada setiap jenis pertanaman. Dengan demikian upaya pengendalian OPT merupakan program pemerintah daerah yang menjadi prioritas pelaksanaannya dilakukan tiap tahun. Penyebaran hama $B$. longissima di Kabupaten Ende hampir merata di beberapa Kecamatan, dari data yang diperoleh memperlihatkan bahwa di Kecamatan Ende, Ende Timur, Ndona dan Ende Utara yang tersebar di 13 Desa dengan luas areal pertanaman $150 \mathrm{Ha}$ yang terdiri dari 15.000 pohon kelapa termasuk dalam kategori intensitas serangan berat (DISHUTBUN, 2008). Tindakan pengendalian yang telah diterapkan dibeberapa lokasi adalah dengan melakukan sanitasi, pemberian pestisida dengan cara absorbsi akar dan pelepasan musuh alami Tetraticliits brontispae (DISHUTBUN, 2008). Pelepasan parasitoid T. brontispe terakhir dilakukan pada bulan Desember 2007 dan Januari 2008 sejumlah 5.220 ekor. Tingkat populasi $B$. longissima di lapang pada saat setelah dilakukan pelepasan musuh alami mengalami penurunan tetapi belum dapat mengendalikan populasi hama pada musim selanjutnya hal tersebut diperlihatkan dengan kemunculan $B$. longissima setiap tahun dengan intensitas serangan berat terutama pada bulan bulan kering dan puncak penyerangannya terjadi pada bulan Januari - April.

Salah satu penyebab gagalnya tindakan pengendalian yang telah dilakukan adalah kurang baiknya system penangkalan disetiap pintu masuk daerah (karantina), sementara itu komoditas kelapa merupakan komoditas yang dibutuhkan oleh semua lapisan masyarakat dan kalangan industri sehingga peredaran dan perpindahan tempatnya sangat cepat. Kegagalan kedua adalah perilaku bercocok tanam petani yang menempatkan kelapa sebagai komoditas sampingan, sehingga teknik budidaya atau cara penanganan OPT tidak dilakukan secara intensif. Meskipun Dinas terkait telah mengupayakan tindakan pengendalian namun kegagalannya akan terjadi di tingkat petani. Ketiga penggunaan musuh alami di lapang memerlukan pendampingan dan pengawalan, karena petani tidak cukup cakap untuk melakukan hal tersebut.

Diperlukan suatu program PHT yang tepat dan menyeluruh agar masalah tersebut dapat terselesaikan. Program PHT tersebut mencakup studi bioekologi hama dan parasitoidnya dan teknik budidaya yang baik. Kegiatan studi bioekologi akan dipusatkan pada pemeliharaan parasitoid dominan dan perbanyakannya yang nantinya akan mengarah pada pelepasan untuk tindakan pengendalian.

\section{ULASAN}

Hama B. longissima merupakan hama yang keberadaannya paling dominan dan selalu muncul setiap tahun. Teknik pengendalian yang telah diterapkan selama ini belum dapat mengendalikan populasi dan menurunkan tingkat serangan hama tersebut di lapang. Hal tersebut dikarenakan belum ditemukannya teknik pengendalian yang tepat dan tidak adanya informasi mengenai faktor - faktor penyebab terjadinya kegagalan usaha pengendalian yang telah dilakukan. Dengan mengetahui bioekologi hama dan musuh alaminya serta mengetahui faktor penyebab gagalnya teknik pengendalian terdahulu merupakan modal dasar dalam pengendalian hama $B$. longisimma selanjutnya.

Keberhasilan suatu tindakan pelepasan parasitoid yang telah dilakukan mempunyai indikator berupa kemapanan parasitoid tersebut secara mudah dan cepat. Hal tersebut berkenaan dengan teori "Three Generation Three Years" yang dikemukakan oleh Ev Chausen seorang ahli PHT dari California bahwa : a) parasitoid/piedator yang efektif secara sempurna selalu mapan secara mudah dan cepat. b) parasitoid/predator yang gagal mapan secara mudah dan cepat merupakan indikator ketidak efektifan musuh alami ' tersebut. c) kolonisasi/pelepasan parasitoid atau predator eksotik dapat dihentikan selama tiga tahun apabila tidak ada bukti kemapanannya di lapang. Untuk itu kegiatan awal yang harus dilakukan adalah dengan mengetahui kolonisasi dan kemapanan parasitoid yang telah dilepaskan terdahulu untuk menemukan teknik pengendalian yang tepat. Disamping itu, perlu diketahui jenis - jenis paraitoid yang ada di lapang dan bagaimana tingkat dominansinya serta kemampuan parasitisasinya dilapang. Sehingga kegiatan pemeliharaan dan perbanyakan akan dipusatkan pada parasitoid dominan dengan tingkat parasitisasi yang tinggi di lapang. Sampai saat ini jenis parasitoid yang telah dilepaskan dan diharapkan mampu mengendalikan populasi $B$. lingossima dilapang merupakan parasitoid yang berasal dari daerah lain, dan belum ada informasi yang lengkap mengenai jenis - jenis parasitoid yang ada di Kabupaten Ende dan tingkat parasitisasinya di lapang. Untuk itu perlu adanya penelitian awal untuk mengumpulkan informasi berupa data akurat yang akan dipergunakan untuk menyusun program PHT yang akan diterapkan.

Langkah awal yang perlu ditempuh yaitu menetahui dengan pasti tentang bioekologi hama 
maupun musuh alaminya, sehingga faktor faktor pendnkung maupun pembatas dalam pertumbuhannya dilapangan dapat dimodifikasi. Adapun bioekologi B. longisima adalah sebagai berikut :

\section{Biologi}

Tehir : berbentuk pipih dan berwarna kecoklatan, diletakkan sendiri atau berkelompok sebanyak 2 - 4 butir pada pada bagian tengah lipatan (Lever, 1979), panjang telur rat a — rata $1,4 \mathrm{~mm}$ dengan lebar rata - rata $0,5 \mathrm{~mm}$ (Tjoa, 1953), masa perkembangan telur antara 3-7 hari (O'Connor, 1940; Waterhouse and Norris, 1987)

Larva : pada saat menetas berwarna bening keputih - putihan kemudian berubah menadi kekuning - kuningan dengan ukuran panjang rata - rata pada saat muncul $2 \mathrm{~mm}$, larva $B$. longissiina menghindari cahaya. Pada bagian ujung depan larva memiliki kaitan berbentuk U. Larva $B$. longissiina mempunyai 4 instar (Froggatt and O'Connor, 1941). Masa perkembangan larva berkisar antara 35 - 54 hari (Lever, 1979).

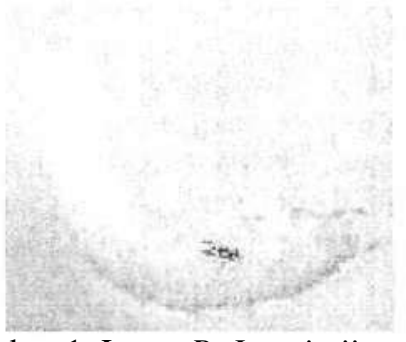

Gambar 1. Larva B. Longissiina

Pupa : pada saat terbentuk pupa berwarna putih kekuning — kuningan dengan panjang rata - rata $9-10 \mathrm{~mm}$ dan lebar $2 \mathrm{~mm}$, fase perkembangan pupa adalah $6-7$ hari (O,Connor, 1940).

Imago : imago jantan memiliki ukuran yang lebih kecil jika dibandingkan dengan imago betina. Panjang imago betina berkisar antara 7,5 - $10 \mathrm{~mm}$ dengan lebar rata - rata 2 mm. Imago berbentuk lonjong dan rata berwarna orange sampai merah tua pada bagian punggung dan berwarna hitam pada bagian kepala dan antena. Brontispa longissiina merupakan serangga nocturnal yaitu serangga yang tidak menyukai cahaya. Pada saat masa non aktif imago $B$. longissiina berada pada bagian tengah lipatan daun sampai imago siap terbang dan menyerang tanaman kelapa pada malam. hari. Serangga betina memproduksi telur rata - rata sebanyak 50 - 100 butir, dengan masa praoviposisi 74 hari atau 1-2 bulan. Lama hidup imago adalah 2 - 3,5 bulan atau 79 - 90 hari. Perkembangan dan telur ke imago adalah 5- 7 minggu, hama tersebut mulai menyerang daun pada umur 2 minggu.

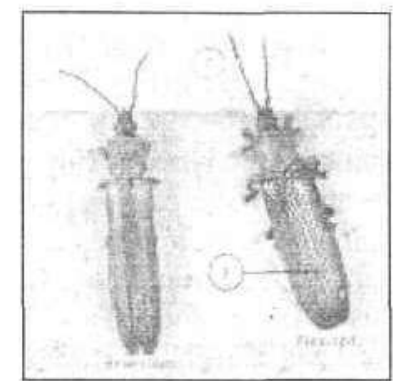

Gambar 2. Imago B. Longissiina

\section{Persebaran dan Tanaman Inang}

Brontispa longissiina merupakan hama pada tanaman bangsa palm - palman, merupakan hama endemik dibeberapa negara termasuk di Indonesia dan Papua Guenia yang persebarannya di Asia tenggara melalui tanaman hias bangsa palm - palman. Sebelumnya hama tersebut tidak pernah dilaporkan di negara - negara Asia Tenggara sampai pada tahun 1990-an sampai ditemukannya hama tersebu di Mekong, Vietnam. Pada tahun 2004 hama tersebut ditemukan di Myanmar, tahun 2005 ditemukan di Pilipina. Kemudian persebarannya beiianjut ke Asia selatan yaitu India, Srilangka dan Bangladesh. Sejak itu persebarannya semakin luas dan tindakan pengendalian yang diterapkan belum membuahkan hasil sehingga hama tersebut menjadi bencana besar pada perindustrian kelapa. Di Vietnam kelapa merupakan tanaman penting yang menjadi sumber penghasilan bagi sebahagian besar penduduknya, terdapat 200.000 ha pertanaman kelapa yang dikelola oleh masyarakat. Kerugian yang diderita dari serangan hama tersebut sebesar 40 juta Dollar AS setiap musimnya (Nakamura, 2006). Di Thailand terdapat 50.000 petani kelapa yang juga mengalami kerugian akibat serangan hama tersebut.

Di Indonesia hama $B$. longissiina ada sejak tahun 1919 - 1934 dan menyebar di berbagai provinsi seperti Jawa Tengah, Jawa Timur, D.I Yogyakarta, Sulawesi Selatan dan Utara. Menurut Joa (1953) B. longissimma Var. Javana ditemukan di Jawa, Bali, Madura, Sumba dan Papua sedangkan B. longissimma Var. Selebensis ditemukan di Sulawesi Selatan dan Utara, Flores, Seram, Kepulauan Aru dan Bogor. Hama tersebut juga telah ditemukan di Sumatera dan Maluku. Suprapto (1983) melalaporkan pada tahun $1980 \mathrm{~B}$. longissiina menyerang tanaman kelapa dengan intensitas serangan berat pada 2.000 ha pertanaman kelapa di Lampung. Madry (1993) memperhitungkan kerugian yang ditimbulkan oleh 
serangan hama B. Longissima pada sembilan provinsi diantaranya : Sumatera Selatan, Lampung, Kalimantan Barat, Sulawesi Selatan, Maluku, Irian Jaya, Bali dan D.I Yogyakarta sebesar Rp. 298.786.000.

\section{Perilaku Makan dan Gejala Serangan}

Brontispa longissima memakan jaringan daun kelapa muda, gejala serangan yang tampak adalah daun berwarna coklat kemerahan, terdapat bekas gerekan pada daun yang merupakan sisa - sisa makanan, sebagai akibat adanya aktivitas makan larva maupun imago daun menjadi mengering, terlipat dan saling melekat akibat kotoran yang ditimbulkan oleh larva dan imago. Pada serangan berat daun mengering hal tersebut mengakibatkan area fotosintesis berkurang ataupun tidak ada sehingga tanaman tidak dapat memproduksi makanan selanjutnya buah gugur dan akhirnya tanaman mati.

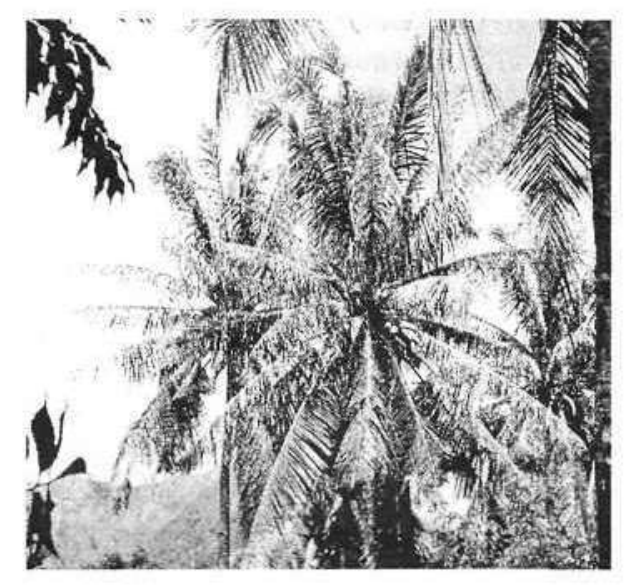

Gambar 3. Gejala serangan B. Longissima di lapang

\section{Musuh Alami}

Pengendalian hayati adalah pemanfaatan aktivitas musuh alami berupa parasitoid, predator dan patogen yang dapat menekan populasi hama di lapang. $\mathrm{P}$ engendalian hayati merupakan metode baru yang diterapkan untuk mengendalikan beberapa jenis hama pada tanaman kelapa (Sathiamma et al, 2001). Sejak musuh alami digunakan sebagai pengendalian hayati, informasi mengenai predator maupun parasitoid pada family Chrysomelidae masih sangat minim.

Beberapa jenis musuh alami $B$. longissima Menurut Lever, 1969 ada berapa jenis parasitoid yang dapat menekan populasi $B$. longissima diantaranya adalah parasit telur yaitu Haeckeliana brontispae Fcrriere,
Trichogrammatoidea nana Zehnter (Hymenoptera : Trichogrammatoidae) dan jenis dari Ooencyrtus (Hymenoptera : Chalcidoidea), parasit larva dan pupa adalah Tetrastichus brontispae Ferriere (Hymenoptera : Eulophydae) dan Asecodes hispinarum Boucek. Sementara itu jenis insect phatogen yang juga dapat mengendalikan populasi B. longissima di lapang adalah Metarhizum anisopliae var. Anisopliae dan Beauveria bassiana

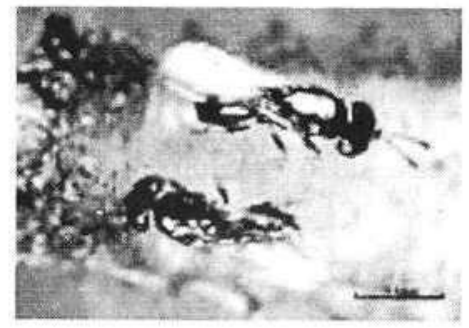

Gambar 4. Parasitoid B. longissima

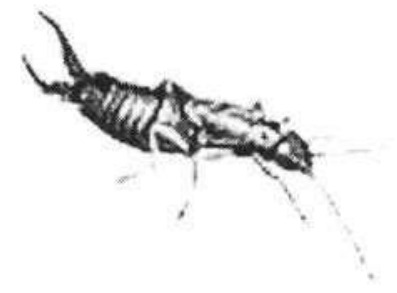

Gambar 5. Predator B. Longissima

Usaha pengendalian $B$. longissima dengan pemanfaatan musuh alami

Menurut laporan dari FAO (2004) dibeberapa negara telah dilakukan pengendalian B. longissima dengan memanfaatkan musuh alami

Cambodia : hama tersebut ditemukan pada tahun 2001, pada pertanaman kelapa seluâs 12.300 ha terserang hama tersebut sekitar 58\% dan $16 \%$ mengalami kematian. Untuk itu diintroduksikan /(. hispinarum pada September 2005.

China : pertama kali ditemukan di kepulauan - Hainan pada tahun 2002, pada tahun yang sama diintroduksi A. hispinarum dari Vietnam dan penggunaan $M$. anisopliae

Indonesia : pengendalian hama tersebut di Indonesia telah dilakukan sejak pertama kali ditemukannya di berbagai provinsi. Tiga musuh alami yang potensial yang dapat dikembangkan adalah $T$. brontispae, $B$. bassiana dan $M$. anisopliae

Laos : hama tersebut ditemukan pada tahun 2001, penanganannya dimulai pada tahun 2004 dengan memanfaatkan A. hispinarum

Malaysia : hama pemakan daun kelapa yang menjadi hama utama di Malaysia pada tahun 2000 
negara lain hal tersebut dikarenakan kelapa bukanlah komoditi penting di Malaysia.

Maldives : kelapa merupakan penggerak utama perekonomian negara, bukan hanya sebagai penghasilan pakan dan pendapatan namun juga berperan penting sebagai komponen pertamanan yang menjadi daya tarik bagi pariwisata. Hama tersebut ditemukan sejak tahun 1999. Pada tahun 2004 dilakukan introduksi A. hispinarum yang diperoleh dari Vietnam. Namun demikian usaha pengendalian tersebut kurang berhasil hal tersebut dikarenakan Maldives mempunyai sekitar 1000 pulau sehingga tidak semua parasitoid mengalami kesesuaian dengan habitatnya.

Myanmar : hama ini di temukan pada tahun 2004 tetapi tidak ada kepastian kerugian yang diderita akibat serangan hama tersebut. Pengendalian dilakukan dengan menggunakan A. liispinantm

Philippina : hama tersebut ditemukan pada tahun 2005 dan pengendaliannya menggunakan A. hispinarum

Sri Lanka -.Plesispa reichei merupakan hama utama pada tanaman kelapa di Si Lanka sementara $B$. longissima serangannya tidak separah $P$. reichei. Pengendalian secara alami menggunakan A. hispinarum

Thailand : hama B. longissima ditemukan pada tahun 2000 dengan intensitas serangan berat. Pada tahun 2004 dilakukan introduksi $A$. hispinarum yang didatangkan dari Vietnam. Pada tahun 2006 telah dilakukan rearing $A$. hispinarum untuk kepentingan pengendalian dikalangan petani.

Vietnam : awal ditemukan hama B. longissima pada tahun 1999 di Mekong. Pada tahun 2002 2004 dilakukan introduksi A. hispinarum sehingga populasi $B$. longissima dapat ditekan sebesar $60-90 \%$.

\section{Pengendalian Hayati}

\section{Faktor Waktu dalam Pengendalian Hayati}

Pada teori "Three Generation and Three Yeras" ditemukan dengan cara menghitung berapa lama waktu yang diperlukan sampai pengendalian hayati itu dianggap berhasil. Dalam teori tersebut tidak dikatakan bahwa keberhasilan tersebut akan permanen. Teori tersebut dapat diterima jika memenuhi ketentuan : (1) Pelepasan parasitoid atau predator telah dilakukan pada semua zone iklim yang telah ditempati oleh inangnya, (2) Koloni yang dilepaskan harus cukup, (3) Pelepasan yang dilakukan harus sinkron dengan waktu dan adanya ketersediaan inang yang cukup melimpah pada stadia yang sesuai, (4) Ketika koleksi penemuan kembali dilakukan maka keberadaan parasitoid atau predator yang telah dilepas cukup banyak, (5) Tidak ada faktor faktor pembatas biologis yang berpengaruh terhadap pcrkembangbiakan yang berkesinambungan.

\section{Pengendalian hayati dengan musuh alami}

Praktek pengendalian hayati saat ini dapat dikelompokkan menjadi tiga kategori yaitu : (1) Introduksi : suatu praktek pengendalian hayati dengan mendatangkan musuh alami dari daerah asalnya. Agar teknik introduksi berhasil dengan baik maka diperlukan persiapan dan studi yang mendalam tentang sifat penyebaran, biologi dan ekologi hama clan parasitoid serta keadaan ekosistemnya, (2) Augmentasi : disebut juga sebagai teknik peningkatan yaitu melakukan pelepasan musuh alami secara berkala ke ekosistem dengan tujuan yang pertama melakukan kolonisasi dan menyebar luas secara alami dalam satu kali pelepasan/musim (inokulatif), kedua yaitu mengembalikan peranan musuh alami untuk melakukan pengendalian (suplemen) dan yang ketiga adalah melakukan pelepasan secara besar besaran agar musuh alami dapat mengendalikan populasi hama dengan cepat (Inundatif). (3) Konservasi : yaitu dengan melakukan modifikasi lingkungan agar ekosistem yang ada cocok bagi perkembangan musuh alami sehingga dapat diharapkan musuh alami dapat melakukan fungsinya sebagai agent pengendalian. Adapun beberapa cara modifikasi lingkungan yaitu dengan melakukan preservasi fase musuh alami yang tidak aktif. penyebaran keanekaragaman komunitas, penyediaan inang alternatif, penyediaan pakan alami (nektar, protein, embun madu), menyediakan suplemen makanan buatan, pembuatan tempat berlindung, pengurangan predator yang tidak diinginkan, pengendalian semut pemakan embun madu, pengaturan suhu yang cocok untuk perkembangan musuh alami, menghindari kegiatan manusia yang dapat merusak ekosistem.

Menurut beberapa ahli bahwa penentu keberhasilan teknik - teknik pengendalian diatas pada umumnya tergantung pada stabilitas agroekosistem pertanaman.

\section{Faktor - faktor yang Mempengaruhi Perkembangan Parasitoid}

Pada umumnya serangga termasuk parasitoid dapat hidup dan berkembang biak dengan baik jika faktor-faktor yang mendukung perkembangannya memenuhi syarat. Menurut Clark et.al (1976) dan Berryman (1981), faktorfaktor tesebut mencakup faktor luar (ekstrinsik) dan faktor dalam (intrinsik). Adapun faktor luar terdiri dari (a) Faktor makanan, seperti jumlah 
makanan, kecocokan makanan, kandungan gizi (protein, karbohidrat, lemak non-esensial, vitamin dan steroi). kadar air yang sesuai dan tanaman inang yang sesuai untuk pertumbuhan dan perkembangannya, (b) Faktor iklim, seperti suhu, kelembaban, cahaya dan aerasi yang baik untuk pembiakan massal, (c) Faktor biologis, termasuk didalamnya adalah musuh alami seperti parasit dan predator, (d) Faktor manusia, yang dimaksud disini adalah sejauh mana tindakan pengendalian serangga hama yang telah dilakukan seperti dengan manipulasi tanaman inang, pergiliran tanaman ataupun pengendalian dengan menggunakan pestisida. Sedangkan yang tercakup dalam faktor dalam adalah (a) Ketahanan ginetik, dimana serangga mampu menciptakan ketahanan secara alami sehingga serangga mampu menyesuaikan did dengan perubahan fisiologis inang atau makanannya sehingga serangga mampu mempertahankan hidupnya, (b) Nisbah kelamin yaitu perbandingan jumlah serangga betina dan jantan, nisbah kelamin dapat menentukan banyak tidaknya jumlah keturunan yang dihasilkan, (c) Kemampuan beradaptasi yaitu sejauh mana serangga mampu beradaptasi dengan perubahan-perubahan iklim pada lingkungan sekitarnya.

Fase inang juga mempengaruhi kesesuaian parasitoid dan kemampuan parasitoid dalam mengatur populasi inangnya (Vinson \& Iwantsch, 1980). Ukuran parasitoid juga berhubungan dengan jumlah telur yang dihasilkan dan efisiensi dalam kemampuan mencari dan memarasit inang. Bila suatu parasitoid memarasit inang instar lanjut maka parasitoid akan menghasilkan masa perkembangan yang lebih singkat dengan nisbah kelamin yang bias betina.

Dengan demikian maka akan diketahui beberapa hal seperti berikut : (1) Kolonisasi dan kemampanan, (2) parasitoid $T$. brontispae yang telah dilepas di lapang, (3) Faktor penyebab $T$. brontispae mengalami kegagalan dalam mengendaliakan populasi $B$. longissima di lapang, (4) Kemungkinan diperlukannya tindakan augmentasi atau konservasi $T$. brontispae di lapang, (5) Kemungkinan $T$. brontispae diperbanyak di laboratorium, (6) Teknik augmentasi, konservasi atau pelepasan yang akan dilakukan, (7) Jenis - jenis parasitoid lokal yang ada di Kab. Ende, (8) Jenis parasitoid dominan, (9) Cara pemeliharaan dan perbanyakan parasitoid, (10) Waktu yang tepat untuk melakukan pelepasan parasitoid dilapang. Data - data yang akan dikumpulkan berkenaan dengan : (1) Tingkat kolonisasi parasitoid yang telah dilepas (\%), Jenis imago parasitoid yang muncul, Dominansi parasitoid yang muncul (\%), Tingkat parasitisasi tiap jenis parasitoid (\%), Nisbah kelamin tiap jenis parasitoid (\%), Keperidian masing - masing parasitoid (\%). Dengan demikian data - data yang diperoleh diatas akan menjadi dasar informasi dalam menyusun program pengendalian yang tepat guna mengendalikan populasi hama $B$. longissima di lapang dan membantu program kerja pemerintah guna meningkatkan mutu dan produktivitas sumberdaya perkebunan.

\section{SIMPULAN}

Untuk mengetahui tingkat keefektivan dari agen hayati yang dilepas perlu dilakukan pemantauan di lapang

Agen hayati yang efektif adalah agen hayati yang mampu menurunkan populasi hama secara kontinyu. mapan dan membentuk kolonisasi yang terbentuk di lapang

Untuk mendukung keberhasilan kinerja agen hayati di lapang maka diperlukan modifikasi lingkungan dengan melakukan preservasi fase musuh alami yang tidak aktif, penyebaran keanekaragaman komunitas, penyediaan inang alternatif, penyediaan pakan alami (nektar, protein, embun madu), menyediakan suplemen makanan buatan, pembuatan tempat berlindung, pengurangan predator yang tidak diinginkan, pengendalian semut pemakan embun madu, pengaturan suhu yang cocok untuk perkembangan musuh alami, menghindari kegiatan manusia yang dapat merusak ekosistem.

\section{DAFTAR PUSTAKA}

Berryman A.A. 1981. Population System. New . York : A General Press.

Clark, L.R., Geler P.W., Hughes R.D., Norris R.F. 1976. The Ecology of Insects Population in Theory and Practice. London : Chapman and Hall.

Dishutbun. 2008. Rencana Stratejik Dishutbun

Tahun 2006 S/d 2008.

FAO. 2004. Report of the Expert Consultations on Coconut Beetle Outbreak in APPPC Member Countries.

Hosang,M.L.A., Jelfina C.A., Novarianto, H. 1996. Biological control of Brontispa longissima (Gestro) in Indonesia. Malayan Agricultural Journal, Vol. 124:37-52

Lever,R.A.W.1951. Malayan Agricultural Journal, Vol. 34:79-82

Nakamura.S., Konishi,K.,Takatsu, K. 2006. Invasion of Coconut Hispine Beetle, Brontispa longissima :Current Situation 
and Control Measures in Southeast Asaia. Malayan Agricultural Journal, Vol. 234:69-73

O'Connor, B.A. 1940. Notes of the Coconut Leaf Hispid, Brontispa froggatti Sharp and its Parasites. The New Guinea Agryculture Gazette. 6:36-40
Vinson, S.B., Iwantsch, G.F. 1980. Host Suitability for Insect Parasitoid. Annu. Rev. Entomol 25 : 397 - 419.

Water House, D.F.. Norris,K.R.1987. Biological Control : Pacific Prospects. ACIAR Inkata Press Melbourne. 134-141 